\title{
Acquired ichthyosis and false-positive hepatitis A serology as paraneoplastic phenomena in anaplastic lymphoma kinase-positive anaplastic large- cell lymphoma
}

\author{
Alexandra Lorna Phillips (10 , ${ }^{1,2}$ Sheena Chantelle Parmar, ${ }^{3}$ Usman Kassim Yakubu, ${ }^{3}$ \\ Mei Fong Chin ${ }^{4}$
}

'Department of Medicine, Cardiff and Vale University Health Board, Cardiff, UK ${ }^{2}$ The Academy, Great Western Hospitals NHS Foundation Trust, Swindon, UK

${ }^{3}$ Bristol Medical School, University of Bristol, Bristol, UK ${ }^{4}$ Department of Dermatology, Great Western Hospitals Foundation NHS Trust, Swindon, UK

\section{Correspondence to} Dr Alexandra Lorna Phillips; alexandra.phillips@doctors. org.uk

Accepted 5 February 2021

\section{DESCRIPTION}

A 54-year-old autoclave technician was referred to the ambulatory care department of a UK district general hospital via his general practitioner (GP) with a 5 -week history of a 'profuse, papery' rash (figure 1A), left groin lymphadenopathy, malaise, myalgia and fevers. He had a medical history of hypertension. Initial blood tests showed an elevated C-reactive protein $(188 \mathrm{mg} / \mathrm{L})$, alkaline phosphatase $(510 \mathrm{U} / \mathrm{L})$ and alanine aminotransferase $(195 \mathrm{U} / \mathrm{L})$ as well as a neutrophilia $\left(9.2 \times 10^{9} / \mathrm{L}\right)$, monocytosis $\left(1.2 \times 10^{9} / \mathrm{L}\right)$ and thrombocytosis $\left(652 \times 10^{9} / \mathrm{L}\right)$. His GP had requested an ultrasound of the left groin; the sonographic appearances favoured reactive lymph nodes, measuring up to $2 \mathrm{~cm}$ each in short axis, that were attributed to his extensive active skin condition.

A liver aetiology screen including abdominal ultrasound revealed positive hepatitis A virus (HAV) IgM, negative HAV IgG and a reactive para-aortic lymph node with normal liver echotexture. He was diagnosed with active HAV infection and reactive

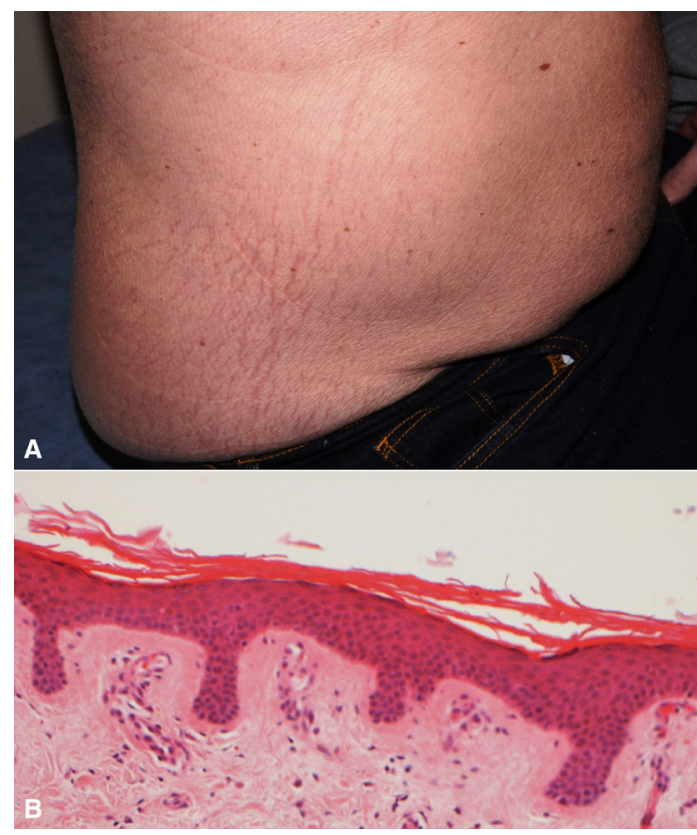

Figure 1 (A) Ichthyosis over the right flank and abdomen. (B) Skin biopsy from the left flank showing mild epidermal orthokeratosis and spongiosis.

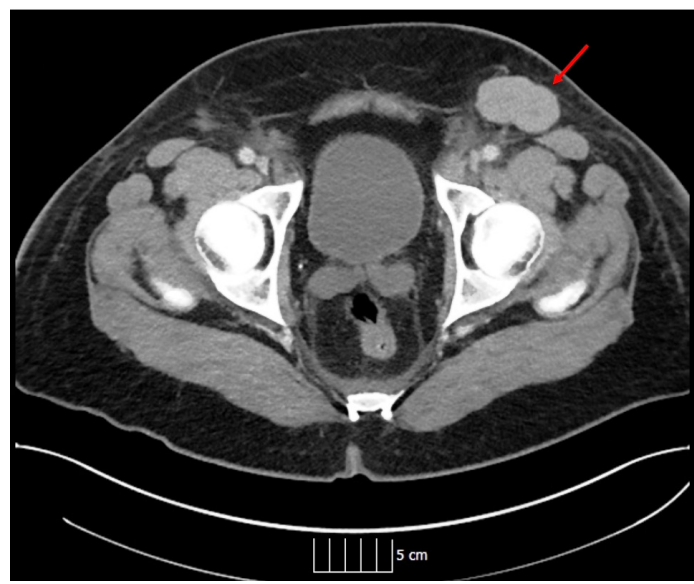

Figure 2 Left groin lymphadenopathy demonstrated on CT scan (arrow).

acquired ichthyosis, which were managed supportively with intravenous fluids and emollients. A skin biopsy from the left flank showed mild epidermal orthokeratosis and spongiosis. The underlying dermis was oedematous with a mild perivascular lymphocytic infiltrate (figure 1B).

The patient developed supraclavicular lymphadenopathy during his inpatient stay, and a CT scan of the neck, thorax, abdomen and pelvis revealed extensive, mostly left-sided lymphadenopathy (figure 2). Lymph node biopsy revealed nodular deposits of lymphoid and plasma cells with clusters and sheets of large atypical multinucleated cells, which were $\mathrm{CD} 3+$, mostly CD20-, CD30+, MUM1+, CD4+, CD5+ and anaplastic lymphoma kinase (ALK) positive. HAV RNA was subsequently found to be negative, as was HAV $\operatorname{IgM}$ when repeated 3 weeks after the initial sample.

The patient was diagnosed with stage III anaplastic large-cell lymphoma (ALCL) and was commenced on treatment. His ichthyosis and hepatic dysfunction resolved rapidly within weeks, and he is now in complete remission following one cycle of cyclophosphamide, doxorubicin, vincristine and prednisolone (CHOP) and five cycles of $\mathrm{CHOP}$ plus etoposide chemotherapy.

Derived from the Greek word for 'fish' due to its scaly appearance, ichthyosis describes a disorder of cutaneous keratinisation that causes the skin to become dry and cracked. It may be inherited or 
acquired, with the latter term referring to those cases caused by an underlying disease process, medication or nutritional deficiency. ${ }^{1}$ Acquired ichthyosis is an established paraneoplastic feature of Hodgkin's lymphoma and has also been reported in a small number of cases of ALCL. This is the first case of ichthyosis associated with ALK-positive ALCL reported in the literature, with ALK expression conferring a more favourable prognosis. ${ }^{2}$

An important confounding feature in this case was a misleading positive HAV IgM, tested as part of a liver dysfunction screen. While the patient did not have any relevant recent foreign travel, his work as an autoclave technician led us to believe that he may

\section{Patient's perspective}

After being sent for an ultrasound by my general practitioner, it was suggested that the lymph node swelling was a result of a skin issue. Later on, I made a number of visits to ambulatory care whereby I was submitting blood tests. During this time, I also had a skin and lymph node biopsy. I got progressively worse and as a result of their findings was placed into quarantine. There was a room but no bed (they then sourced one). I was later released and returned to a ward a week later by my haematology consultant after cancer diagnosis. It took the Christmas period to ascertain which type of lymphoma I had. My all-round care including outpatient care was generally outstanding, and I am particularly thankful to my haematology consultant for her quick reaction and support; she was incredible. I must also mention the junior doctor for her caring support and the various consultants who helped me to get through this. The chemotherapy unit women and outpatient staff were also very professional and caring and kept me smiling. Many thanks to all.

\section{Learning points}

- Lymphoma should be considered as a differential diagnosis in all patients presenting with acquired ichthyosis.

- Positive serological tests for infectious and autoimmune diseases should be interpreted with caution in patients presenting with signs and symptoms consistent with lymphoma. have been exposed to the virus. HAV IgM usually becomes undetectable 6 months after infection, ${ }^{3}$ and as the patient reported no other recent illness nor vaccination for HAV, we presume that this was a false-positive result likely related to his diagnosis of ALCL. False-positive serology has been reported previously in T-cell lymphomas including ALCL for various diseases including Lyme disease, ${ }^{4} \mathrm{HIV}^{5}$ and coeliac disease, ${ }^{6}$ with resolution of positive antibody tests after treatment of the lymphoma. There are no previous published cases of false-positive serology for HAV as a paraneoplastic feature of lymphoma.

\section{Twitter Alexandra Lorna Phillips @DrAlexPhillips}

Acknowledgements The authors are grateful to Dr Lawrence John, Consultant Pathologist at Great Western Hospitals NHS Foundation Trust, for reviewing the histology and providing the histology image for this manuscript, and to Dr Chris Jacobs from The Academy at Great Western Hospitals NHS Foundation Trust for his support and feedback on manuscript drafts.

Contributors Dr ALP wrote the manuscript and obtained patient consent. Mr UKY and Ms SCP contributed equally and undertook the literature search as well as reviewing and editing manuscript drafts and providing comments. Dr MFC provided a dermatological opinion on the patient's case, performed the skin biopsy, reviewed manuscript drafts and advised on significant revisions to this.

Funding The authors have not declared a specific grant for this research from any funding agency in the public, commercial or not-for-profit sectors.

Competing interests None declared.

Patient consent for publication Obtained.

Provenance and peer review Not commissioned; externally peer reviewed.

\section{ORCID iD}

Alexandra Lorna Phillips http://orcid.org/0000-0001-7236-9227

\section{REFERENCES}

1 Patel N, Spencer LA, English JC, et al. Acquired ichthyosis. J Am Acad Dermatol 2006;55:647-56.

2 Savage KJ, Harris NL, Vose JM, et al. ALK- anaplastic large-cell lymphoma is clinically and immunophenotypically different from both ALK $+A L C L$ and peripheral T-cell lymphoma, not otherwise specified: report from the International peripheral T-cell lymphoma project. Blood 2008;111:5496-504.

3 Stapleton JT. Host immune response to hepatitis A virus. J Infect Dis 1995;171 Suppl 1:S9-14.

4 Deeren D, Deleu L. False positive Borrelia serology and facial paralysis due to anaplastic lymphoma mimicking Lyme. Acta Clin Belg 2012;67:56

5 Shida S, Takahashi N, Fujishima N, et al. False-Positive human immunodeficiency virus antibody test and autoimmune hemolytic anemia in a patient with angioimmunoblastic T-cell lymphoma. Intern Med 2011;50:2383-7.

6 Carroccio A, Fabiani E, lannitto E, et al. Tissue transglutaminase autoantibodies in patients with non-Hodgkin's lymphoma. Case reports. Digestion 2000;62:271-5.

Copyright 2021 BMJ Publishing Group. All rights reserved. For permission to reuse any of this content visit

https://www.bmj.com/company/products-services/rights-and-licensing/permissions/

BMJ Case Report Fellows may re-use this article for personal use and teaching without any further permission.

Become a Fellow of BMJ Case Reports today and you can:

- Submit as many cases as you like

- Enjoy fast sympathetic peer review and rapid publication of accepted articles

- Access all the published articles

- Re-use any of the published material for personal use and teaching without further permission

Customer Service

If you have any further queries about your subscription, please contact our customer services team on +44 (0) 2071111105 or via email at support@bmj.com.

Visit casereports.bmj.com for more articles like this and to become a Fellow 